\title{
Synthesis of Vinyl Sulfides using Selenium Ionic Liquid
}

\author{
Samuel Thurow, Samuel R. Mendes, Diego Alves, Gelson Perin, Raquel G. Jacob \\ and Eder J. Lenardão*
}

\author{
Laboratório de Síntese Orgânica Limpa, Universidade Federal de Pelotas, UFPel, Pelotas, RS, Brasil \\ *e-mail corresponding author: lenardao@ufpel.edu.br
}

Keywords: Vinyl Sulfides, Hydrothiolation, Ionic Liquid

\section{INTRODUCTION}

Vinyl sulfides are very versatile and useful intermediates in organic synthesis ${ }^{1}$ and there are several compounds of natural occurrence bearing the vinyl sulfide group isolated from bloming plants of the tribe Heliantheae (Asteraceae). ${ }^{2}$ In addition, vinyl sulfides can be converted into the corresponding aldehyde, ketone or carboxylic acid or ester by acid hydrolysis or through the thioClaisen rearrangement. ${ }^{3}$

On the other hand, ionic liquids (ILs) constitute an interesting alternative to solvents in organic synthesis. Because product isolation or catalyst recycling is very easy in ILs and, in some cases, rate accelerations and/or selectivity improvements are also observed, they are regarded as environmentally friendly green solvents. ${ }^{4}$ Due our continuing interest in the synthesis and applications of organochalcogenium chemistry and in new applications for selenium-based ionic liquids, ${ }^{5}$ we decide to study the use of $[\mathrm{bmim}]\left[\mathrm{SeO}_{2}\left(\mathrm{OCH}_{3}\right)\right]$ for the synthesis of vinyl sulfides by hydrothiolation of terminal alkynes.

\section{RESULTS AND DISCUSSION}

A set of experiments were performed to find the best conditions for the synthesis of vinyl sulfides using thiophenol and propargyl alcohol as model compounds (Scheme 1).

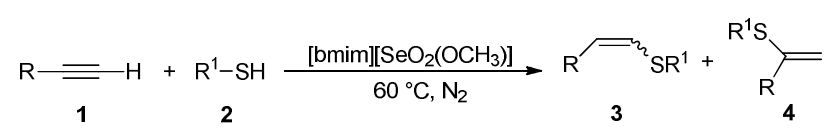

Scheme 1. Synthesis of vinyl sulfides.

Careful analysis revealed that the best yields were obtained when a mixture of alkyne $(1.2 \mathrm{mmol})$, thiol $(1.0 \mathrm{mmol})$ and $[\mathrm{bmim}]\left[\mathrm{SeO}_{2}\left(\mathrm{OCH}_{3}\right)\right](15.8 \mathrm{mg}, 5$ mol\%) was vigorously stirred at $60{ }^{\circ} \mathrm{C}$. Thus, the respective product was obtained in $81 \%$ yield after 16 hours (Table 1 , entry 1 ).

With this optimized conditions in hand, a study was performed with aliphatic and aromatic thiols and propargyl alcohol and phenylacetylene, showing the generality of the method. For most examples, good yields were obtained (Table 1).
Table 1. Synthesis of vinyl sulfides using ionic liquid.

\begin{tabular}{|c|c|c|c|c|}
\hline Entry & Product & Time (h) & 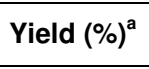 & $\begin{array}{c}\text { Ratio }^{\text {b }} \\
\text { 3E.3Z: } 4\end{array}$ \\
\hline 1 & & 16 & 81 & $25: 52: 23$ \\
\hline 2 & $\mathrm{C}_{8} \mathrm{H}_{5} \mathrm{CH}_{2} \mathrm{~S}_{3 \mathrm{~b}}$ & 16 & 67 & $44: 53: 3$ \\
\hline 3 & 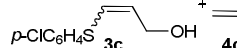 & 15 & 70 & $31: 57: 12$ \\
\hline 4 & ${ }_{6} \mathrm{H}_{4} \mathrm{~S}_{3 \mathrm{~d}}^{5-}$ & 19 & 71 & 27:73:0 \\
\hline 5 & $\mathrm{C}_{12} \mathrm{H}_{25} \mathrm{~S}^{\mathrm{S}^{3}}{ }_{3 \mathrm{e}}$ & 12 & 53 & 44:54:2 \\
\hline 6 & $\mathrm{C}_{6} \mathrm{H}_{5} \mathrm{~S}^{5}$ & 17 & 55 & $19: 74: 7$ \\
\hline 7 & $\mathrm{C}_{6} \mathrm{H}_{5} \mathrm{~S}^{3}{ }_{3 \mathrm{~g}} \mathrm{C}_{6} \mathrm{H}_{5}$ & 2 & 91 & $42: 54: 4$ \\
\hline
\end{tabular}

In summary, the method described is very simple, clean and efficient for the synthesis of vinyl sulfides using $[\mathrm{bmim}]\left[\mathrm{SeO}_{2}\left(\mathrm{OCH}_{3}\right)\right]$, being a useful alternative for the existing methodologies. The reaction proceeds easily and the products were obtained in good yields.

\section{ACKNOWLEDGEMENTS}

The authors thank FAPERGS/PRONEX 10/0005-1, PNPD/CAPES, and CNPq for financial support.

\section{REFERENCES}

${ }^{1}$ Corey, E. J.; Shulman, J. I. J. Am. Chem. Soc. 1970, 92, 5522; Waters, M. S.; Cowen, J. A.; McWilliams, J. C.; Maligres, P. E.; Askin, D. Tetrahedron Lett. 2000, 41, 141; Imanishi, T.; Ohara, T.; Sugiyama, K. Ueda, Y.; Takemoto, Y. J. Chem. Soc., Chem. Commun. 1992, 269.

2 Sorensen, N.A. In The Biology and Chemistry of the Compositae; Heywood, V. H.; Harborne, J. B.; Turner, B. L., Eds. Academic Press: London, 1977, Vol. 1.

Fortes, C.C.; Fortes, H.C.; Gonçalves, D.R.G. J. Chem. Soc., Chem. Commun. 1982, 857.

${ }^{4}$ Welton, T. Chem. Rev. 1999, 99, 2071; Dupont, J.; Souza, R. F.; Suarez, P. A. Z Chem. Rev, 2002, 102, 3667; Martins, M. A. P. Frizzo, C. P Moreira, D. N.; Zanatta, N.; Bonacorso, H. G. Chem. Rev. 2008, 108, 2015.

${ }^{5}$ Thurow, S. ; Pereira, V. A.; Martinez, D. M.; Alves, D.; Perin, G.; Jacob, R. G.; Lenardão, E. J. Tetrahedron Lett. 2011, 52, 640. 